\title{
En cours de publication
}

The South African Urban System, in C. Rozenblat, D. Pumain and E. Velasquez (eds) International and Transnational perspectives on Urban Systems, Springer, June 2018

\section{The South African Urban System}

Solène BAFFI, Geography Department, Stellenbosch University, Stellenbosch, South Africa, solene.baffi@gmail.com

Ivan TUROK, Human Science Research Council, Cape Town, South Africa, iturok@hsrc.ac.za

Céline VACCHIANI-MARCUZZO*, University Reims Champagne-Ardenne, UMR 8504

Géographie-cités, Reims, France, vacchiani@parisgeo.cnrs.fr

*: Corresponding author

Abstract

South Africa is often considered an unusual and extreme case in geography. One difficulty is whether to label this a developing country (like its neighbouring countries), a former colony (like the United States and Australia), or an emerging economy (like the BRICS group), because of its highly diverse and unevenly developed character. South Africa also bears a strong imprint of its colonial and apartheid history, with long-lasting, path-dependent effects. This special status alludes to the complex territorial trends that characterise the country. The heterogeneous settlement dynamics and differentiated social, economic and political systems have exerted a powerful influence over urbanization trends. The chapter explores whether these trends are distinctive compared with other countries, and what specific socio-economic challenges are faced in the urban areas.

Keywords : South Africa - urbanization trends - urban trajectories - social exclusion

\section{Introduction}

South Africa's urbanization differs from what can be observed in other African countries in various respects. First, South Africa urbanised earlier than other parts of subSaharan Africa because of its distinctive economic history of mineral extraction and associated industrialisation. By the late- $19^{\text {th }}$ century it was still a sparsely-populated territory with a largely agrarian society and extensive arid regions, but with a few localised areas of great industrial dynamism. These emergent cities quickly became powerful drivers of growth with substantial multiplier effects on the economy of the whole region and far-reaching social consequences as 
they suctioned large quantities of labour from the wider sub-continent. The urban population of the country rose rapidly during the $20^{\text {th }}$ century, and the number of urban areas increased more than ten-fold. The urban share of the national population increased from about $17 \%$ in 1900 to about $65 \%$ today, making South Africa one of the most urbanised countries on the continent (Turok, 2014).

Second, the pattern of urbanisation in South Africa has been deeply influenced by its extreme political history. The promulgation of segregation laws at the beginning of the $19^{\text {th }}$ century and the implementation of "separate development" during apartheid caused a departure from trends observed elsewhere and produced a distinctive form of urban growth. Urbanisation accelerated during the first half of the $20^{\text {th }}$ century and then slowed down. Rapid industrialisation during the first period attracted more and more people from the countryside to migrate towards the cities in search of livelihoods. The growing black African population in the cities produced a negative reaction from the ruling white minority group, which resulted in stringent state controls to restrict further urbanisation. Although the controls did not stop the process, they dampened it, particularly at the height of apartheid between the late-1950s and early-1980s (Turok, 2014). Access to living space for Africans, Coloureds and Indians became dependent of the Group Areas Act at the urban scale, and the implementation of "displaced urbanisation" at the national scale with the creation of so-called homelands. These laws imposed a very restrictive and uneven urbanisation on the country's development path.

Third the removal of restrictive laws and the opening of the country to global economic forces in the 1990s led to the imposition of new spatial dynamics onto the inherited patterns. The polarization of economic activities has been reinforced by the adoption of orthodox macroeconomic measures, namely the Growth, Employment and Redistribution programme in 1998. The inherited socio-spatial inequalities constitute major challenges for the different spheres of national, provincial and metropolitan government. Indeed, the difficulties of addressing the inherited inequalities are exacerbated by the state's reluctance to constrain private actors in their choice of location. The desires for economic connections to international networks and to gain visibility on the international stage have tended to concentrate development within restricted areas in the biggest cities. These dynamics partly explain why South Africa remains one of the most unequal countries in the world, with a Gini index of $63.4 \%$ in 2011 according to the World Bank (Todes and Turok, 2017).

In order to better understand the main characteristics of urbanization in South Africa, this chapter seeks to identify the various dynamics of urbanization over the long term by identifying their distinctive features from those of cities in general. In order to achieve this, various approaches have been privileged. A first concern regards the evolution of the structure of the urban system over the long term (2), followed by a specific focus on the economic trajectories of the main agglomerations (3). The analysis of the socio-spatial reconfigurations linked with public policies implemented since 1994 then enlightens the current challenges and innovations faced in South African cities (4).

\section{Main trends in urbanization since the $17^{\text {th }}$ century}

\subsection{Dynamics of urbanization of a new country since the $17^{\text {th }}$ century}

According to the European definition of human settlements at the time, no city existed before the Dutch colonists established the Cape settlement in 1652 (Coquery-Vidrovitch, 1993). Even though settlements existed in the area established by Bantus or Khoisans, they did not form the highly structured pattern of European settlements. However, the goal of the Dutch colonists 
was not to initiate an intensive colonization of the space located at the tip of Africa. The main raison d'être of the Cape settlement was its strategic position on the international maritime road. Nevertheless, after a few years the discoveries of natural resources in the hinterland brought colonists to establish various small settlements within the Cape Colony. Those pioneer fronts were not driven the colonial authority but were a consequence of private initiatives by scattered groups of individuals, the trekboers. From this moment on, the position of the Cape settlement as an interface located on international trade routes and a bridgehead towards an unknown hinterland became its main role as a settlement. This situation can be compared to other new countries such as the United States and Canada, even though the number of settlers was fewer in South Africa. However the local economy and society remained quite rudimentary. The weakly developed aspect of the Dutch colony enabled R. J. Davies (1972) to talk about a "pre-industrial stage" to qualify the Cape Colony between 1652 and 1806 . The agrarian economy remained dominant at this time, few communication networks were built and the main mode of transportation was the ox-wagon, resulting in lengthy journeys to connect Cape Town to its surrounding settlements. Therefore, in spite of the foundation of towns at the time, the lack of integration between the various settlements makes it impossible to refer to the existence of an urban system as yet.

The strategic position of the Cape of Good Hope on the maritime routes explains why the British wanted to seize this space, while in Europe French, Dutch and British empires fought to consolidate their supremacy. In 1806, the Cape settlement became a British possession, the new colonists having the aim to make the Cape an important harbor able to export sheep wool to the expanding English industry (Houssay-Holzschuch, 1999). The initial ambition of the British therefore differed radically from the goals defined by the Dutch when they founded the colony. Moreover, the colonial territorialization pattern developed by the British relying on transport and communication networks (McKenzie, 1927) to assert control over the land, meant that the meshing together of the new colony was quickly established. The colonists operated a thin administrative division followed by the foundation of new towns to relay the Crown's power within the hinterland. A postal service was created in 1806, followed a few decades later by the implementation of the telegraph in 1860. Roads were built as well as bridges and passes to facilitate the access to the interior of the country, while omnibus services were inaugurated in Cape Town to enable increased commuting into town. The construction of the railway network in 1860 marked a turning point in the connectivity of the territory. The frequency of the maritime connections between Cape Town and Britain increased along with the speed of the vessels following the introduction of steam engines. These changes contributed to a shift in the South African colony's position in the international system: from an unknown periphery, the territory was slowly integrated into the British Empire, with major repercussions for its internal organization.

The simultaneity of the construction of the railroads and the discovery of a rich hinterland where the British needed to assert their domination influenced the position of the new towns. Indeed, the reticular pattern implemented led to the foundation of towns along the new rail communication axis (Fig.1). At this stage, the South African network fits with the model developed by E. J. Taaffe, R. L. Morrill \& P. R. Gould (1963): penetrating lines appeared to serve different ambitions: establishing political and military connections, and producing agricultural goods for export. Hence, the railways network was developed according to what can be observed in other African colonies: the penetrating lines were connecting the main harbors to areas of agricultural production such as the wine lands or the breeding areas, especially to export ostrich feathers and sheep wool (Baffi, 2014). At the time, the networking of the colony combined with the influx of British and European immigrants, the economic dynamism of the settlers and the political and administrative organization contributed to 
structuring the space located at the tip of the continent, turning Cape Town into a proper bridgehead for Southern Africa.

\section{Figure 1: Spatial diffusion of railways in South Africa}

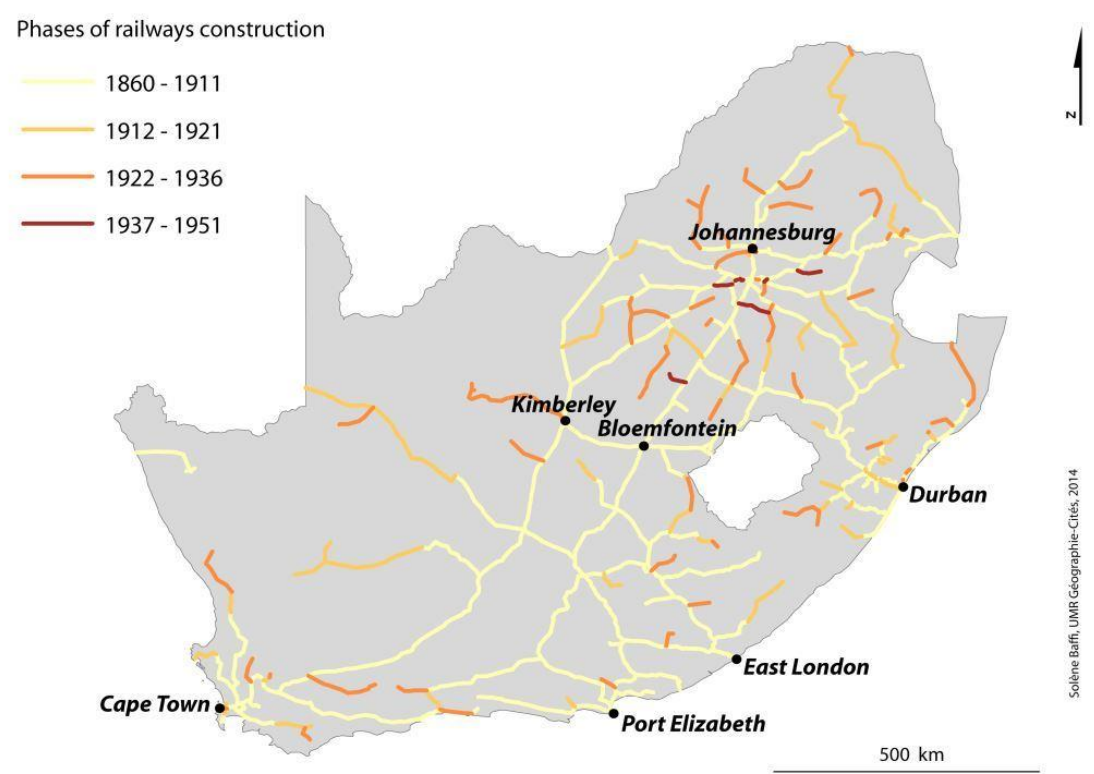

This pattern evolved quickly when rich mineral discoveries were made in Kimberley in 1867 and the Witwatersrand in 1886. These discoveries led to a gold rush and the foundation of Johannesburg, as well as other small mining towns along the 80 kilometer-long ore deposits. The need to carry heavy machines from the seaports to the Witwatersrand in order to extract the gold was one of the reasons for the rapid extension of the railway line towards Kimberley and then Johannesburg: in 1892, a train from Cape Town entered Johannesburg. The dynamism of the industry was also attributable to the influx of a large workforce: low skilled workers mostly Africans - reached Johannesburg by train from the most remote parts of South Africa and neighboring countries, whereas qualified workers arrived from England or other British colonies. The importance of the population influx to Johannesburg explains why only ten years after its foundation, its population exceeded Cape Town's. Hence, the mining discoveries in Johannesburg led to a major upheaval in Southern Africa due to the synergies between urban growth, industrialization and extension of the railways. Three railway lines were built in the 1890s to connect the Witwatersrand with the commercial ports of Maputo, Durban and Cape Town, based largely on public funding (Turok, 2014). If the coast contained the largest towns and the economic and political centers during the colonial era, the exceptional growth of Johannesburg brought about a switch in the urban structure: the center of gravity in the urban system and the railway network moved towards the interior of the country (Fig.2), starting a profound and persistent pattern of spatial polarization (Browett \& Fair, 1974).

Figure 2: Spatial diffusion of cities and railways in South Africa 


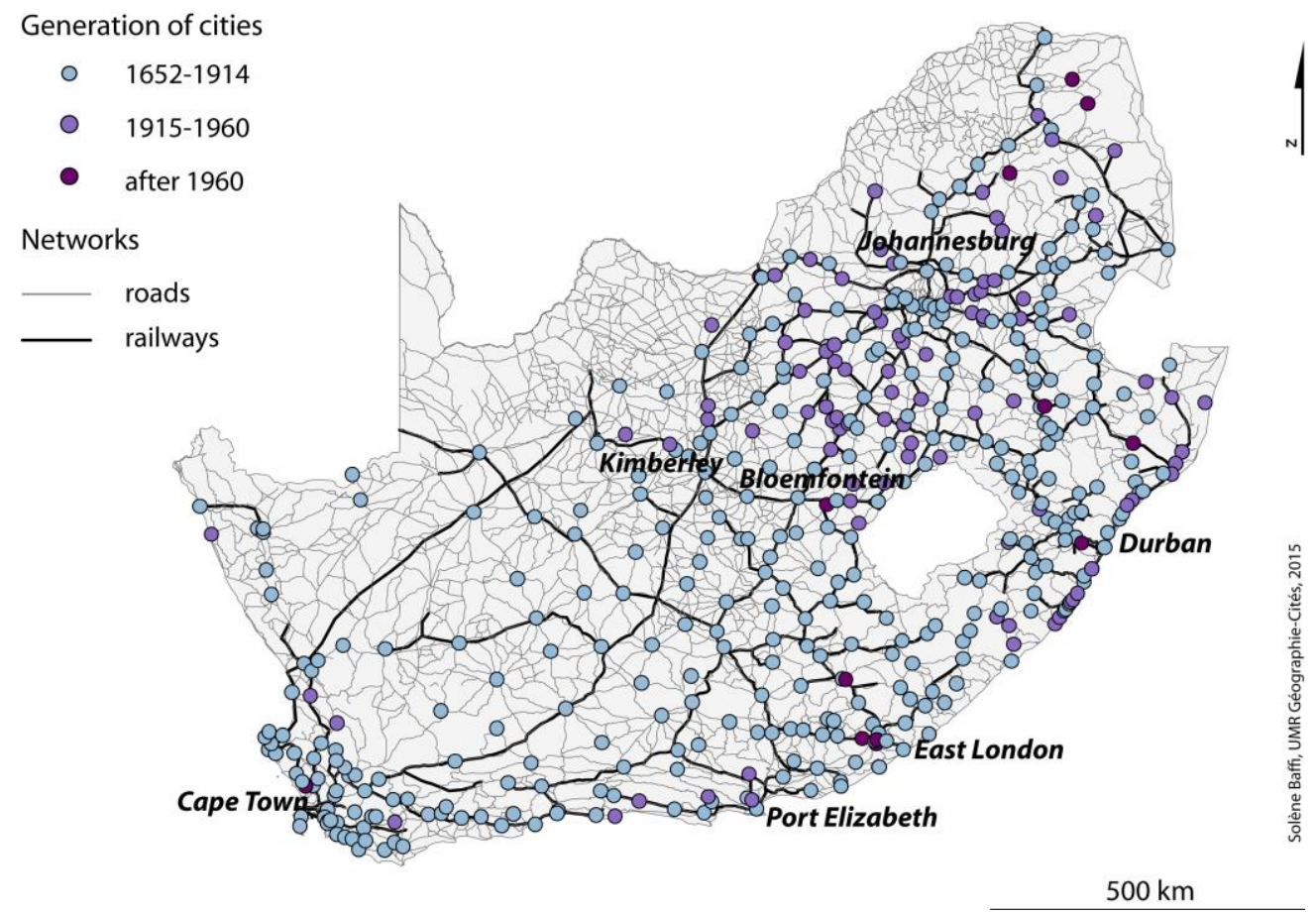

Structural upheavals in the organization of space were also attributable to major political changes at the end of the $19^{\text {th }}$ century. The South of Africa was by then divided between two Boer Republics, two British Colonies and various native African states. Access to the gold mines by the railways constituted an object of tension between Boers and British, and one of the triggers leading to the Boer War in 1899. The victory of the British was revealed by the fusion of the different railway companies at the beginning of the $20^{\text {th }}$ century, deepening the strong connection between State and railways in South Africa. This connection reached its peak in 1910, when the establishment of the Republic of South Africa is immediately followed by the foundation of the South African Railways. Therefore, the intertwined logics of urbanization and space networking by the railways at the end of the $19^{\text {th }}$ century strongly contributed to create a stable urban structure. 


\section{BOX: defining the "urban" in South Africa over the long term}

A major challenge faced by geographers is to define what is urban and what is not in a way that is consistent over time. Urban areas are usually defined administratively, statistically, morphologically or functionally. However, in South Africa the implementation of segregation and forced removals reduced the applicability of these criteria. The creation of separate homelands and townships that lacked an economic base deprived these settlements of the functions and high order services that normally exist for places of this size. This undermines the use of a functional criterion. The morphological criterion is also problematic because the geography of apartheid kept populations physically separate, with major discontinuities in space in order to isolate the different racial groups. In towns, buffer zones were created to separate white areas from townships (Coloured, Indian or African). There were also long distances between the urban centers and many of the former homelands, despite their functional dependence. The administrative criterion is not useful either because different racial zones within each city were administered by separate bodies during apartheid.

Throughout the $20^{\text {th }}$ century a legal definition of the city was adopted in the official censuses. This is a satisfactory approach in most countries. However, because of South Africa's tumultuous history, where political action shaped the territory, the legal definition appears unstable. For instance, the definition of 'urban' adopted in 1960 clearly excluded the non-white parts of towns. These and other inconsistencies undermine the use of a legal definition to compare cities over the long term. It explains the need to use a new administrative grid and definition after the democratic transition in 1994. Since the 2001 census, the work conducted by Statistics South Africa has been valuable. They published a report assessing the main challenges in defining cities in South Africa and offering a new definition based on a morphofunctional criterion. This enabled a more inclusive definition of 'urban' spaces that incorporated places that were previously excluded, despite their functional connections, such as suburbs, townships and towns in the former homelands.

The database Dysturb (Giraut \& Vacchiani-Marcuzzo, 2009) was built according to this morpho-functional definition and a consistent interpretation of what is urban over the long term (1911-2011). This required the connections between a main urban area and its immediate peripheries to be considered. These include commuting journeys which are identifiable through a specific transport system, black taxis, or minibus taxis. These connections were essential to make choices in order to create a robust and valid spatio-temporal database. A minimum threshold of 5000 inhabitants was still used once the links between each former white town and its functional periphery were established.

\subsection{Main trends in urban growth (1911-2011)}

Between 1870 and 1930, there was the most marked acceleration in the growth of new towns in the history of South Africa (Giraut, Vacchiani-Marcuzzo, 2009 ${ }^{1}$ ). The combination of this phenomenon and the political unification of the country by way of the Union Act in 1910 led to a continuous reinforcement of territorial cohesion in the course of the $20^{\text {th }}$ century. Thereafter, the situation in relation to the main lines of communication, in particular the railways, was a determining factor with the region around Johannesburg becoming a railway centre that was essential in the process of urban growth. A more secondary event occurred in the 1920s in the form of a prolonged drought, which accelerated population migration from the countryside to the towns. The speed of evolution was linked to the economic upheavals in the

\footnotetext{
${ }^{1}$ Source: Giraut F., Vacchiani-Marcuzzo C. 2009. Territories and Urbanization, Atlas and geo-historical information system (DYSTURB). Paris: IRD éditions, CD Rom, 80 p.
} 
last decade of the "late Colonial Transition stage", which was an economic expansion phase, characterised by the healthy mining sector (in the Transvaal - present-day Gauteng - and Orange Free State) and by the intensification of agriculture, in the course of which the foundations of the industrial expansion of the 1930s were laid. Unprecedented rural exodus, mainly made up of Afrikaner farmers, fed the growth of towns in this period. The decisive factor, after the discovery of mineral wealth, was the intense industrial development from 1933. The rapid economic expansion, which accelerated with the industrial era, progressively affected the major part of the South African territory in a variety of ways (Fig.3).

The creation of towns after 1933 was concentrated in the most dynamic industrial regions, in particular the mining interior. A succession of new settlements emerged in different places and for different reasons (Vacchiani-Marcuzzo, 2016). For example, new entities were created after 1960, during the apartheid period, and located in the Bantustans or in the peripheries of the main urban areas, intended to act as de-concentration points to reduce the growth of the black population in the main cities (Atlantis, to the north of Cape Town for instance). The establishment of an urban system, seen through the successive waves of new urban development, shows that the system is younger than in Europe, that growth has been fast, and closely linked to economic and political upheavals (Giraut, Vacchiani-Marcuzzo, 2009).

\section{Figure 3: Evolution of South African urban pattern from 1911 to 2011}

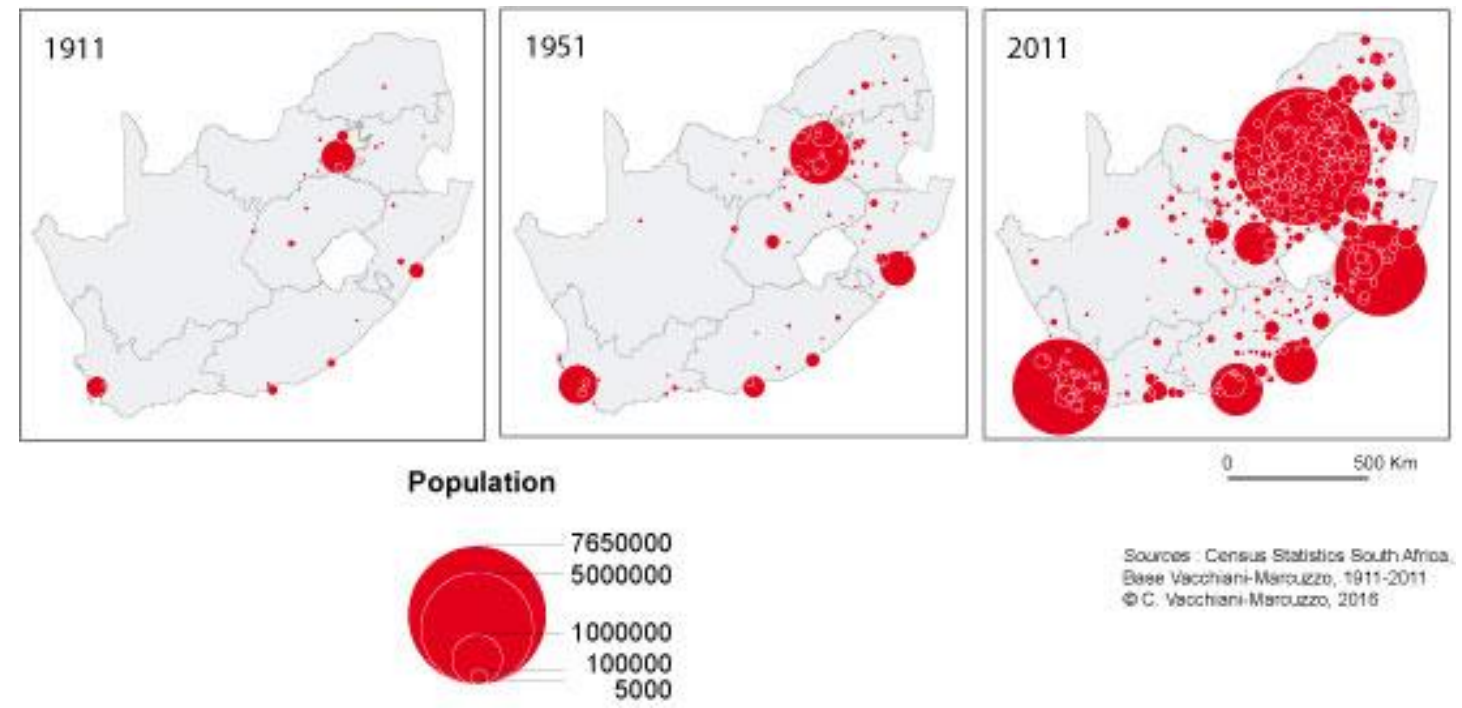

Urbanisation was suppressed between the 1950 and the 1980s by stringent apartheid restrictions on migration. Influx controls restricted the flow of the black population towards the towns and cities $^{2}$ and were implemented by way of pass laws. These were removed in 1986 as the apartheid system disintegrated, and the rate of urbanisation rebounded (Tab.1). The coincidental decline of manufacturing industry and the growth of business, financial and consumer services have also had distinctive spatial implications, including the growth of Gauteng and other

\footnotetext{
${ }^{2}$ The Native Urban Areas Act of 1923 marked the start of urban segregation, well before the official introduction of apartheid. It underpinned all subsequent legislation. The Act gave municipalities the power to create quarters reserved for Africans. In addition, the text established a system of population control (influx control) involving "passes" which carried the name of the employer, and enabled black workers to leave the native population reserves to go to work in town. At the outset, the system was not widely observed. Indeed the periods in which the mining industry developed and industry expanded created considerable demand for labour in the towns and cities, so that influx control was relaxed in most towns. The text was later strengthened by an amendment in 1937 (Giraut, Vacchiani-Marcuzzo, 2009).
} 
metropolitan areas. Many mining towns to the West of Johannesburg and in the Free State have declined, while service-oriented economies, such as Pretoria and Cape Town, have prospered.

Table 1: Level of urbanization 1911-2011

\begin{tabular}{|c|c|}
\hline Year & Urbanization rate (\%) \\
\hline 1911 & 18.2 \\
\hline 1921 & 19.8 \\
\hline 1936 & 25.8 \\
\hline 1951 & 35.2 \\
\hline 1960 & 37.9 \\
\hline 1970 & 38.5 \\
\hline 1980 & 42.5 \\
\hline 1991 & 45.6 \\
\hline 1996 & 53.4 \\
\hline 2001 & 56.6 \\
\hline 2011 & 64.1 \\
\hline
\end{tabular}

Thus, despite a relatively high level of urbanization at the national level (64\% in 2011), South Africa is still characterised by marked spatial disparities. The different features inherited from their histories that were mentioned earlier led to migratory flows that contributed to a complex territorial structure (Giraut, Vacchiani-Marcuzzo, 2009). In more precise terms, the different phases of urbanisation generated three main zones of urban concentration, although without any phenomenon of macrocephaly, which is unusual for the African continent. The primacy index ${ }^{3}$ between the first and second urban agglomerations is only 2 . In addition, the degree of urbanisation is unequally spread among the provinces (nine in number since the end of apartheid). Gauteng province, which includes the three metropolitan areas of Johannesburg, East Rand (Ekurhuleni ${ }^{4}$ ) and Pretoria (Tshwane) obviously heads the list with an urbanised population level of 99.6\%, followed by Western Cape Province (95.1\%). At the other extreme Northern Province has a proportion under 20\%. Thus the provinces are at different stages of urban transition, and with considerable differences between regions. Different cities and towns across South Africa perform different functions and interact with each other in multiple ways.

\subsection{The resilience of urban hierarchy}

The strong regularity and stability of the rank-size distribution of settlements across the century (1911-2011) is noteworthy (Fig.4). The graphs are parallel in terms of evolution and similar for the composition of the head of hierarchy. Indeed, the same metropolitan areas stay at this upper level over the decades (Johannesburg, Cape Town, Durban, Tshwane).

Figure 4: Rank-Size of South African Urban agglomerations (1911-2011)

\footnotetext{
3 The primacy index has been calculated since Jefferson (1939) by measuring the relationship between the population of the first city and that of the second (P1/P2). F. Moriconi-Ebrard (1993) proposed a generalisation of this notion, distinguishing as metropolises the city or cities situated immediately above the greatest discontinuity threshold in the distribution of city size $(\mathrm{Pi} / \mathrm{Pj} \max )$ and named this the macrocephaly index. It is therefore not the same measure, but in theory if $\mathrm{a}=1$ in Zipf's law, it can be expected that $\mathrm{P} 1 / \mathrm{P} 2=2$. In practice, the worldwide mean according to F. Moriconi-Ebrard should be around 4 or 5 .

${ }^{4}$ The renaming of municipalities affected the names of most of the metropolitan areas.
} 


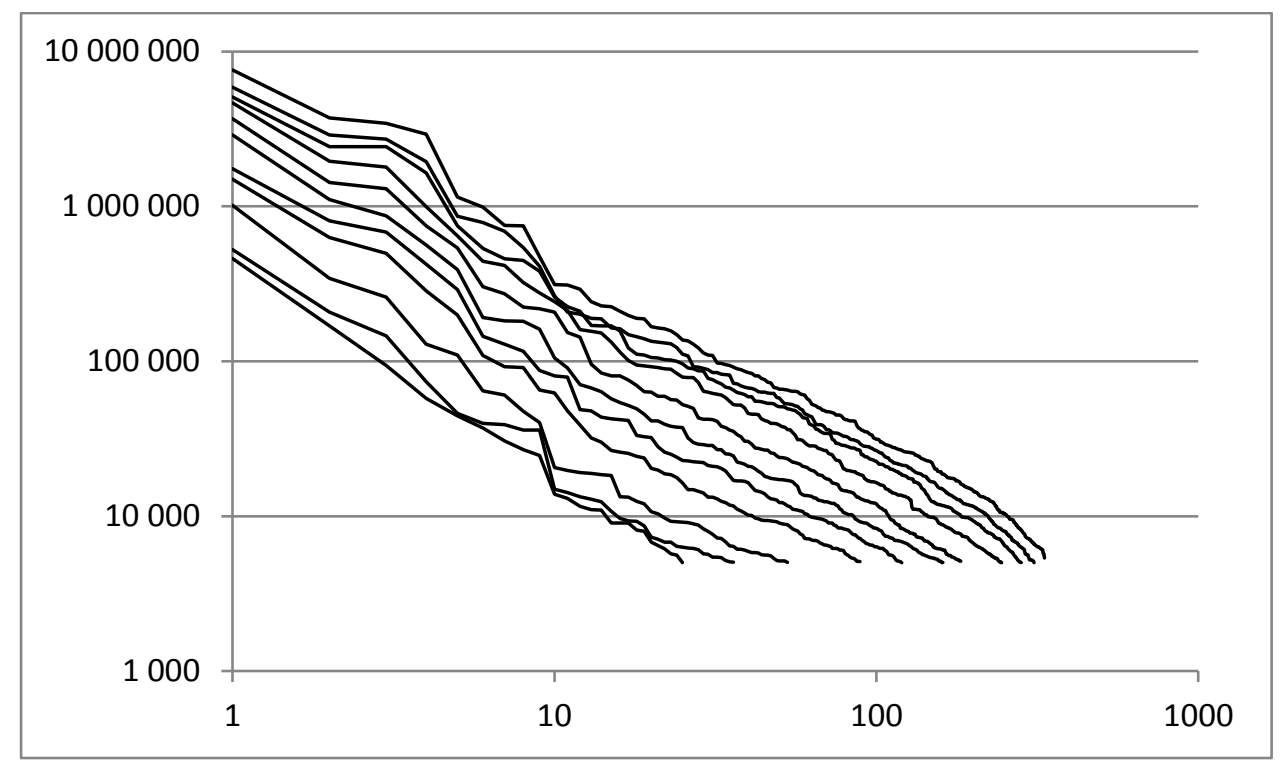

Source : Stats SA, Frith website, Base Vacchiani-Marcuzzo, 2011

Different stages clearly appear on the rank-size graphs:

- The most visible feature is the persistence in the shape of the distribution. The curves show no major distortions and evolve in a similar way. The decreasing slope value (Fig.5) between 1911 and 1971 is also relevant to a territory filling in and an urban system in progress. The configuration of the largest cities proves that the system doesn't show any macrocephaly at the national scale, the head is composite and not unique.

- A first threshold is detectable, depending on the year, at the upper level of the hierarchy, between the $3^{\text {rd }}$ and $4^{\text {th }}$ agglomeration or the $4^{\text {th }}$ and $5^{\text {th }}$ (since 1970) or even between the $5^{\text {th }}$ and $6^{\text {th }}$ agglomeration. This first level is certainly representative of the distinction between cities and metropolitan areas ${ }^{5}$.

- A second threshold is observed around the $10^{\text {th }}$ agglomeration, especially until 1936. A clear gap appears that is not found in the following years. The towns being concerned are East London and Grahamstown in 1911 and Kimberley and Uitenhage in 1936. One possible interpretation is that there is a stage between two levels of the urban hierarchy, between medium-sized cities and small towns. It is important to note that the threshold, which would then allow the identification of small or middle-sized cities, varies over time and it evolves with the growth of cities.

- A third threshold is related to a specific period and observed at local scale. The first census post-apartheid in 1996 requires inserting former homelands in urban agglomerations. For example, for Pretoria, the growth rate is high between 1996 and 2011 because of the absorption of population (displaced urbanization) from parts of Bophuthatswana in the functional urban area of Tshwane. This period post-apartheid is also characterized by a stabilization of the slope values (more or less 1.2), that is very similar with other "new countries" like in USA and more important than in European countries.

Except in these specific cases, Apartheid is not really noticeable as a disruptive element in the urban system dynamics. This may be surprising but the main trend over the years is the resilience and the inertia of the system. The legacy of apartheid is more noticeable in the case of displaced urbanization and at the intra-urban scale. Moreover, even though the process of

\footnotetext{
${ }^{5}$ R. J. Davies (1972) notes the same threshold in his study of the rank-size curve in 1960 and interprets it as the
} distinction between the "middle-sized cities" (intermediate cities) and "metropolitan cities" (cities). 
drawing new administrative boundaries was very intense during the 1990s (new provinces, new municipalities boundaries, neo-toponomy, etc.), its impact on urban evolution and urban growth is not obvious at the scale of urban system.

Figure 5: Inequality in city sizes in South Africa (1911-2011)

\begin{tabular}{|c|c|}
\hline Date & Slope \\
\hline 1911 & 1.39 \\
\hline 1921 & 1.329 \\
\hline 1936 & 1.311 \\
\hline 1951 & 1.21 \\
\hline 1960 & 1.165 \\
\hline 1970 & 1.165 \\
\hline 1980 & 1.218 \\
\hline 1991 & 1.215 \\
\hline 1996 & 1.196 \\
\hline 2001 & 1.188 \\
\hline 2011 & 1.197 \\
\hline
\end{tabular}

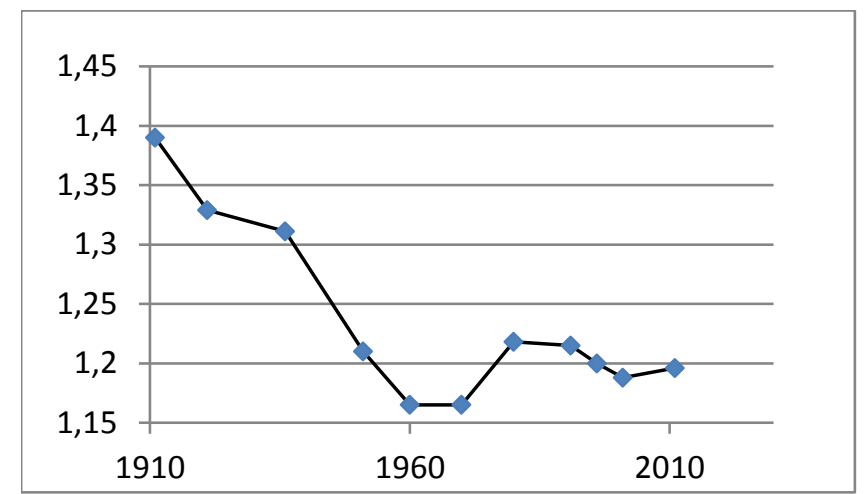

Source : Stats SA, Frith website, Base Vacchiani-Marcuzzo, 2011

\section{Urban economic trajectories}

\subsection{Functions and specializations of the major cities over the long term}

The dynamics of urbanization in Gauteng (formerly Witwatersrand), Cape Town and Durban were all rather different because their economies had different structures.

\section{Strong urban nodes in Gauteng: Johannesburg and Pretoria}

Gauteng was dominated by gold mining and gradually diversified into associated manufacturing industries and services. These included chemical explosives (for mining), metal manufacturing, timber and other building materials, civil and mechanical engineering, and electricity production and distribution. Mining companies themselves were directly involved in establishing subsidiaries producing cement, clothing, food, beer, steel, chemicals and paper. Mining also prompted the emergence of the financial services industry, which has replaced mining as Johannesburg's leading economic sector for the last two decades (Harrison \& Zack, 2012). Gold mining remained the engine of the South African economy for almost 100 years, and was for many years almost the only source of export revenues. In the 1930s the gold mines were estimated to account for 50 per cent of all state tax revenues (Turok, 2014). By the peak of gold production in 1970, South Africa contributed no less than 78 per cent of global output of gold. Such was the direct importance of gold mining to Gauteng. The expansion of mining in Gauteng had major local multiplier effects, both indirect and induced. The indirect effects were experienced across a range of supplier industries, as indicated above.

The largest concentration of manufacturing industry was in a constellation of nine towns in Ekurhuleni (formerly the East Rand) to the East of Johannesburg. They were Bosburg, Benoni, Alberton, Brakpan, Germiston, Kempton Park, Edenvale, Springs and Nigel. The East Rand became the heartland of the country's manufacturing economy, with sizeable clusters of firms engaged in metal working, chemicals, food and drink, and packaging. Manufacturing was 
complemented by important support services in air transport, rail, warehousing and telecommunications. The area became a major logistics hub, including the busiest airport (OR Tambo), highway interchange (Gilloolys), and railway hub (Germiston) in the whole of Africa.

The induced effects of mining were also experienced across diverse sectors. Construction was a major activity concerned with building houses for the rapidly expanding population and other premises for all the associated public and private services. Retail and distribution sectors grew rapidly to meet the consumption needs of the spiralling population. The composition of the labour force of Gauteng changed radically in the 1970s and 1980s, with a dramatic reduction in the use of foreign workers on the mines and their replacement by domestic labour (Turok, 2014). Foreign workers accounted for nearly 80 per cent of South Africa's mining workforce in the early 1970s, but political transitions in Mozambique and elsewhere prompted large-scale withdrawal. The number of domestic workers employed on the mines rose rapidly from 87,000 in the mid-1970s to 333,000 in the mid-1980s (Harrison \& Zack, 2012). This was driven by rising wages, trade union recognition, and worsening economic conditions in the homelands. The substitution of local for foreign workers gave a bigger boost to Gauteng's consumer industries, because remittances were smaller and more workers and their families settled permanently within the city-region. Several manufacturing sectors in Gauteng also benefited from South Africa's international isolation during the 1960s and 1970s, which encouraged import substitution and industrial diversification. However, the foreign sanctions and trade barriers created a somewhat artificial business environment with limited competition. Many domestic companies suffered badly when these protections were suddenly withdrawn in the 1990s. Their management capabilities, workforce skills and technologies were generally below international standards and they struggled to compete against foreign producers (Bhorat et al, 2014). The economy has also suffered from a volatile exchange rate and unstable labour relations.

After a period of economic stagnation and enormous political upheaval in the late-1980s and early-1990s, there was a negotiated transition from Apartheid and democratic elections were held in 1994. This ushered in a period of unprecedented political stability and a modest economic recovery (Turok, 2014). Mining remained important to the national economy, but there was a shift from gold to coal and platinum. These minerals were not located in Gauteng, but in surrounding provinces, such as Mpumalanga and North-West.

The Johannesburg economy diversified with some success from mining and manufacturing to business and financial services and consumer services. Johannesburg now accommodates the headquarters of all the major banks and most insurance companies in South Africa. It is also a major centre for higher education and entertainment. Retail activities in the city benefit from sizeable inflows of visitors and traders from other Southern African countries who come to the city to buy goods for sale or consumption back home. Ekurhuleni experienced serious deindustrialisation during the 1990s and has struggled to diversify into other industries. However, it continues to benefit from logistics, warehousing, hotels and other activities linked to OR Tambo Airport. It is seeking to mobilise support to create an Aerotropolis in the vicinity of the airport to boost logistics and high value manufacturing industries.

The city of Tshwane (formerly Pretoria) has been the administrative (executive) capital of South Africa and the centre of the civil service since 1910. It houses the headquarters of the main government departments and ministries, the headquarters of the military and police forces, and all the foreign embassies and diplomatic missions. Tshwane is also a major commercial and industrial centre, although smaller than Johannesburg. The main industries are motor vehicles, steel, pharmaceuticals, heavy machinery, aerospace and military equipment. It is one of the country's leading centres of higher education and research, with the largest residential university (Tshwane University of Technology), the largest distance education university 
(UNISA) and a leading research and teaching university (University of Pretoria). Important scientific and cultural institutions include the Council for Scientific and Industrial Research, Human Sciences Research Council, Medical Research Institute, Agricultural Research Council and many museums. The public sector forms an unusually large part of the city's economy, both as a source of employment and of demand for property in the city. This has been beneficial in protecting the city from the worst effects of the global recession and deindustrialisation over the last decade. Hence Tshwane appears to have a more stable and resilient economy than Johannesburg and Ekurhuleni, but perhaps also less dynamic because of the dominance of the public sector.

\section{Durban: An embattled coastal city}

Durban is the largest trans-shipment point for imports and exports to Gauteng and other cities and towns in the interior. It has never possessed the administrative functions of the other four major cities, so its growth during the $20^{\text {th }}$ century was based on transport, manufacturing and commercial activities. Durban is the country's largest port by far, and the logical place to establish ship repair facilities and industries based on imported inputs, such as chemicals, food and drink, paper, printing and engineering (Freund \& Padayachee, 2002). Many of these sectors grew strongly between the 1950s and 1980s. Durban municipality became a pioneer during this period. It was actively involved in acquiring land to assemble sites for industrial development and expansion. It also introduced a system that put the burden on black workers to pay for the cost of their own housing and welfare, with no cross-subsidy from the better-off white ratepayers (Freund and Padayachee, 2002). This involved creating a monopoly on the production of beer and setting up municipal beer-halls and eating houses for Africans.

Durban's economy has underperformed relative to the other major cities in South Africa since the 1990s. One reason for this is the greater dependence on manufacturing. Durban has not diversified in the same way as Johannesburg and Cape Town. The city has had some success in attracting automotive manufacturing, with a major Toyota assembly plant and many of its suppliers. However, many other industries have suffered from poor competitiveness and import penetration. Clothing and textiles is a prime example. It was once a mainstay of the local economy, but it has since been decimated by cheap imports from Asia. Durban also suffers from the lack of provincial and national government departments located in the city. It has therefore lost out from the sizeable growth in public sector jobs in the country over the last decade. 


\section{Cape Town: from Mother city to innovative city}

Cape Town thrived as the economic and administrative centre of the Cape Colony during the $19^{\text {th }}$ Century, and subsequently as the legislative capital of the Republic of South Africa, with a range of associated logistics, manufacturing, cultural, media, property, financial, educational and tourism activities (Bickford-Smith et al., 1999). Textiles, clothing and furniture were particularly important for many years. Cape Town also prospered with the head offices of major companies in retailing, financial services, business services and oil refining (Turok, 2014).

Since the 1990s, the city has benefited from the growth of many service industries, although not on the same scale as Gauteng. The city is the headquarters of several financial services companies, international retail chains, media/publishing houses and construction companies. Tourism has become increasingly important with the diverse attractions of the Western Cape for entertainment and sightseeing. These include Table Mountain, the Cape Peninsula, appealing beaches, vineyards, historic buildings and towns, quality hotels and restaurants. Call centres and business processing operations have also been expanding in the city, most of which are owned and controlled by multinational corporations. The city has experienced growth in a range of creative industries, including ICT, design and film production, partly linked to the attractive lifestyle and image of the city. Finally, the government plays an important role in the local economy, with the provincial and municipal headquarters, the national parliament, three universities and major hospitals.

\section{Smaller metropolitan and urban areas}

The leading secondary cities are Nelson Mandela Bay (Port Elizabeth), Buffalo City (East London) and Mangaung (Bloemfontein). The economic performance of all three has been lacklustre for the last two decades. All three have suffered from the decline of manufacturing and an inability to diversify into other industries. The automotive sector has provided slight relief for Nelson Mandela Bay and Buffalo City, with reinvestment by established multinationals. The public sector has been a much more important source of employment over the last decade, and provided a lifeline to offset the effects of deindustrialisation.

The economic base of other secondary cities is even narrower. Former gold-mining cities and towns such as Welkom (now called Matjhabeng) and Klerksdorp (now called Matlosana) have suffered badly from mining cutbacks and closures. In complete contrast, Rustenburg has been the fastest growing town in the country over the last decade. Its growth is attributable to the rapid expansion of platinum and chrome mining and associated processing activities. It has the four largest platinum mines and the largest platinum refinery in the world.

\subsection{Urban economic profiles in the early $21^{\text {th }}$ century}

A general overview of trajectories of cities in economic space since the 1960 s can be approached by the shift from "old" to "new" industries (Fig.6). Indeed, as observed in more prosperous countries, the economic profile reveals a change around the 1980s with urban functions more focused on advanced activities such as financial, insurance, telecoms and real estate (FIRE) and business services (Advanced Producer Services). This well-known shift towards the tertiary economy occurred in South African cities 10 to 20 years later than in European or US cities. It's particularly true for metropolitan areas whereas secondary cities have more traditional structures, based on manufacturing and mining. 


\section{Figure 6: Main trajectory of economic profile of cities from 1960's}

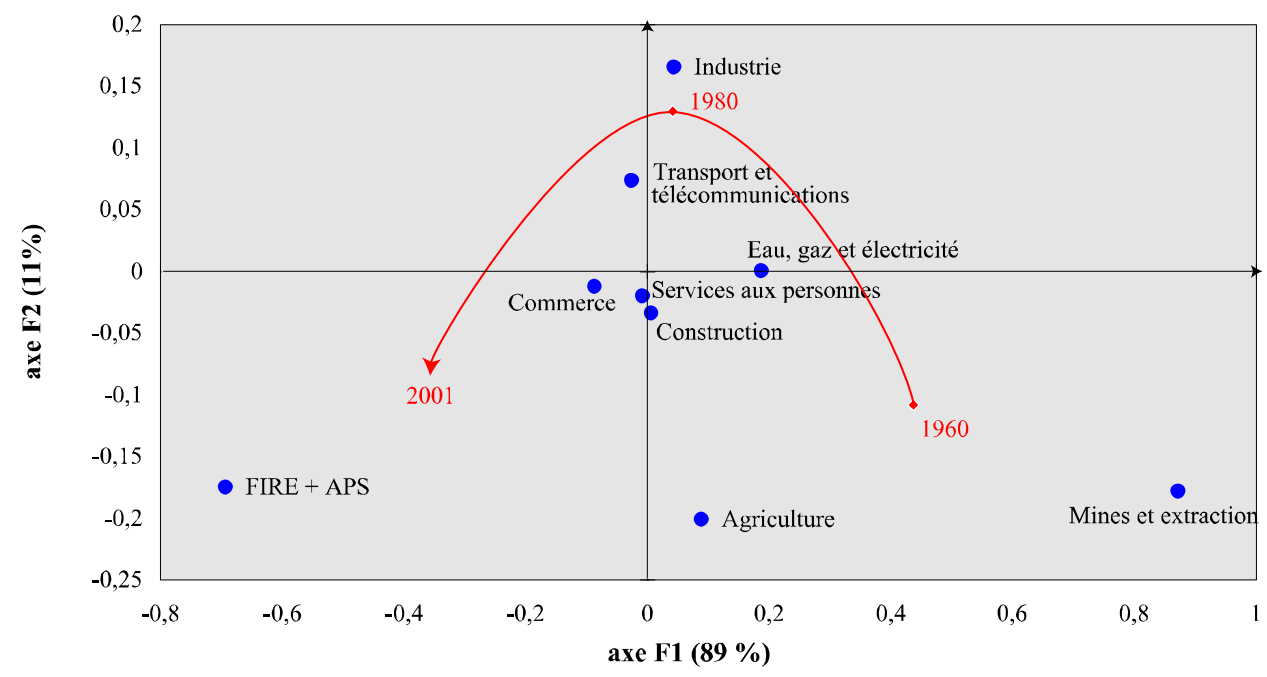

Even though South African cities differ according to their stage of economic and technological development, a process of catching-up is also observed. Nowadays, the urban profile in terms of economic diversification reveals a strong similarity with others countries.

As large cities adopt innovative cycles (Paulus \& Vacchiani-Marcuzzo, 2016), they keep the footprints of past cycles, so their functional profile appears more diverse and complex (Pumain et al., 2006). This hypothesis, already tested in other territorial contexts, is based on the number of employees in the different economic sectors in cities, according to South African economic nomenclature, very similar to international standards. In this early 21 th century, South African largest cities appear globally less specialized than smaller ones (Fig.7), and this is independent of any regional effect and the level of economic development. The relationship between city size and economic diversity appear more evident on the figure 8. All large urban agglomerations belong to the most diversified group of cities whereas less diversified cities are only small ones (Pumain et al., 2009).

Figure 7: Economic diversity and city-size in South Africa

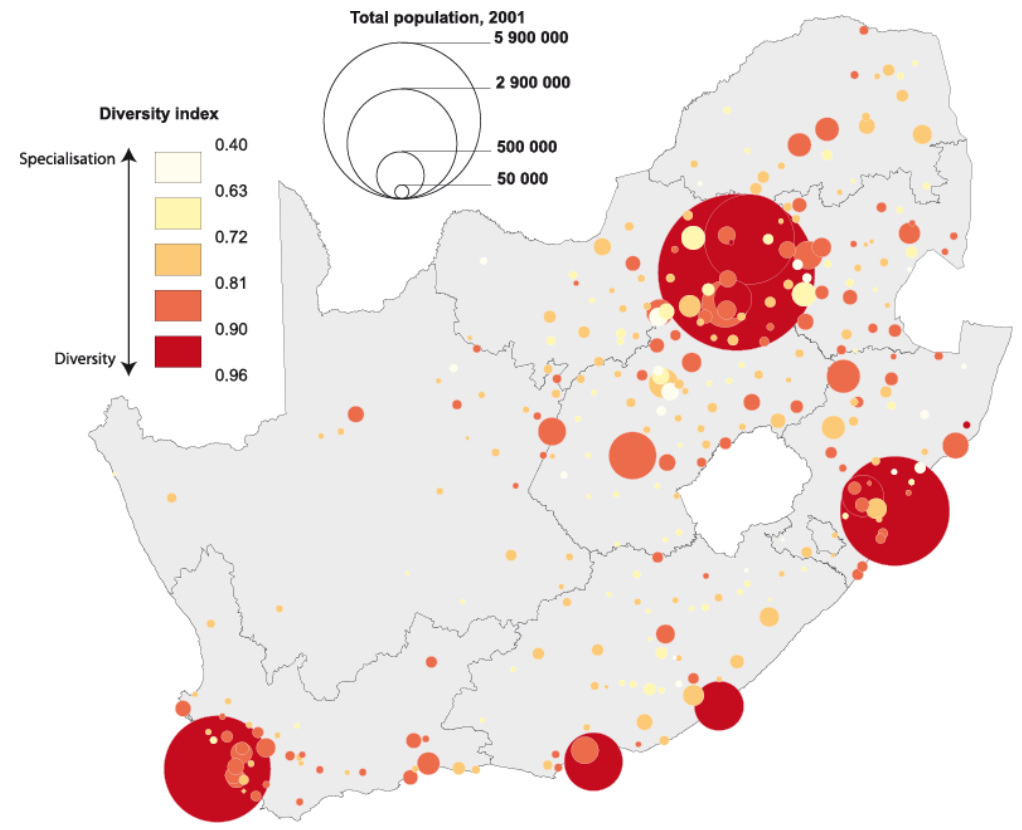

(C) Vacchiani-Marcuzzo, 2005 
Following this global diversity index, the economic profile of urban agglomerations can be approached through another quantitative analysis as scaling laws (Pumain et al., 2006) and through the measure of scaling parameters on economic sectors. In economic landscape at the world scale, leading sectors issued from innovation cycles are mainly driven by business services. A clear reversal occurred after the 1970s in the productive system with the huge development of business services, research and development and simultaneously the decay of manufacturing, at least according to employment data (Fig.8).

\section{Figure 8: City's size and economic diversity}

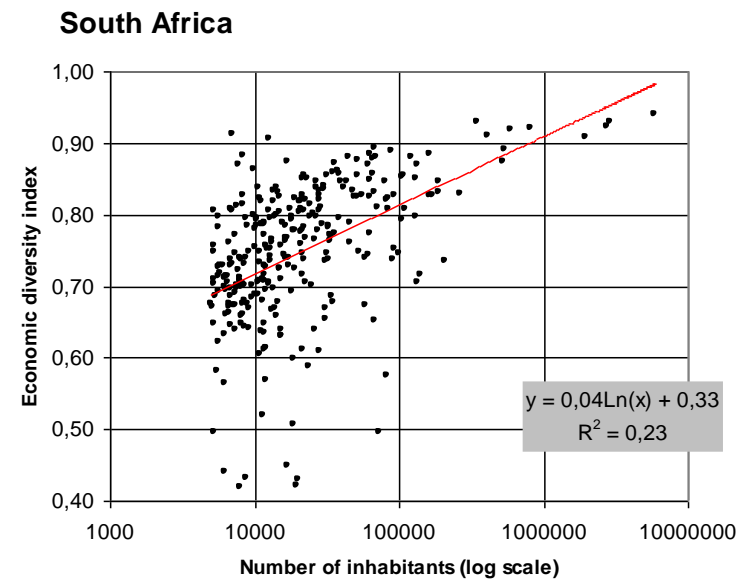

(C) Vacchiani-Marcuzzo, 2016

An example of one of these services can be the sector of finance activities because it is a good proxy of the leading current innovation cycle. In South Africa (Fig.9), the $\beta$ exponent for the equivalent sector of FIRE (Finance, Insurance and Real Estate) is clearly above 1(1.2). For one part, it reveals that South Africa cities are part of the global pattern, more precisely, the head of the urban hierarchy. But, the sector of manufacturing is also high $(\beta=1.3)$. It proves the emerging profile of South Africa, a country "space between" or hybrid where the diversification of industry occurred later than in others countries (and at the same time it was very early on the African continent). It's the same with the sector of Transport and Communication, a leading sector in this emerging economy.

Figure 9: Scaling parameters in economic sectors (2001)

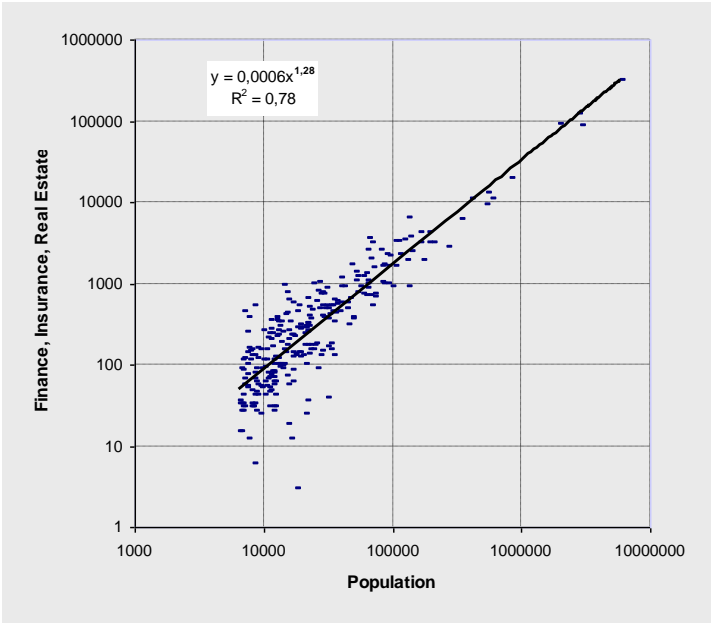

FIRE (Finance, Insurance and Real Estate)

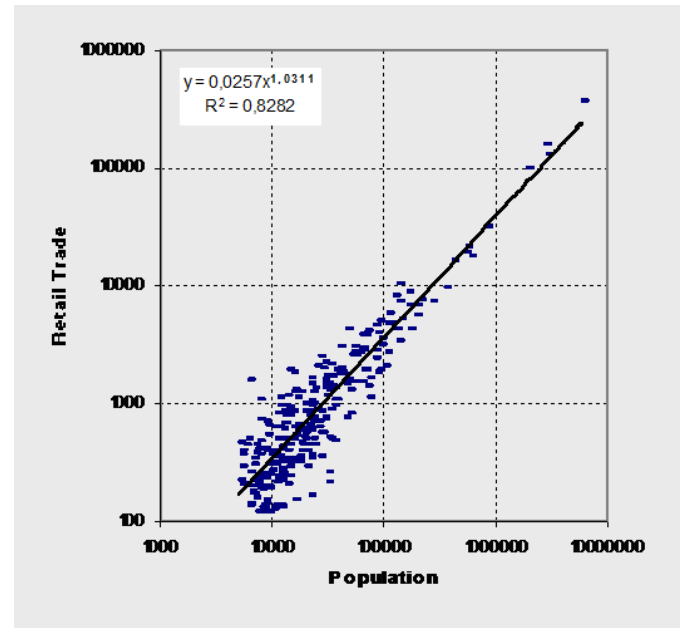

Retail Trade

(C) Vacchiani-Marcuzzo, 2016 
Other kinds of activities appear more widespread in the whole urban system ( $\beta$ value close to 1) like the retail sector. The private household sector (with a majority of domestic services) has a $\beta<1(0.90)$ which reveals a very common sector, located in all cities and such activities comprise domestic workers, with around 1.5 million people.

\subsection{Continental and international economic leadership/role}

\subsubsection{How to exist at the world level?}

The emphasis in the preceding discussion is on the differences between cities. There are also some important common issues affecting all or most cities in South Africa. Their poor economic performance by international standards is crucial. The South African economy has generally under-performed other middle-income developing countries (including Brazil, Malaysia, Turkey, Indonesia, Philippines, India and China) on all key indicators - exports, investment, competition, innovation and productivity (Bhorat et al., 2014). All South African cities suffer from exceptional levels of inequality and unemployment. The rate of unemployment varies between $20-40 \%$, depending on how it is defined. High unemployment is attributable to slow growth in economic output, which in turn is attributable to low productivity growth and low investment. Economic growth since the 1990s has been driven by household consumption rather than productive investment. Consumer debt has increased and is now a severe constraint on household spending. The structure of the economy is skewed towards a few key sectors which are either highly capital intensive and create few jobs directly (such as the automotive industry), or highly skill intensive and create few low-skilled jobs that are accessible to unemployed people (such as financial services). Compared with many other developing countries, the informal economy is very small and does not help very much to absorb unemployment (Bhorat et al., 2014). Small businesses struggle to compete against established companies and suffer from large regulatory burdens. Manufacturing industries that have traditionally been large employers, such as clothing, textiles, footwear, furniture and electrical equipment, have been in decline.

The levels of inward foreign direct investment are low by the standards of other middle-income countries and outweighed by short-term financial flows in the form of portfolio investment. Many observers believe that South Africa is caught in a middle-income growth trap because of its failure to diversify from the minerals-energy-complex and move up the value chain towards innovation-based products and services (Fig.10). Consequently, exports remain dominated by mineral ores and metals because the country has failed to develop more technologically sophisticated, higher value added products for export. Two exceptions are insurance/financial services and tourism. Additional constraints on the development of a more dynamic economy have been high port handling charges for exports, high costs of rail freight and highly regulated telecommunications and energy sectors which limit competition and raise costs (Bhorat et al., 2014).

City economies were relatively self-contained prior to the 1990s because of sanctions against South Africa, except of course for the export of minerals. Since then deindustrialization has been severe and cities are struggling to position themselves in a more competitive international environment. Tourism is important in Cape Town, Johannesburg and Durban, to a lesser extent. Johannesburg is also an important shopping center for people from the rest of Southern Africa. Durban is a logistics gateway to the rest of southern Africa. Since 1994 the context of the South African economy has been transformed from a position of relative isolation from the international economy to reinsertion and reintegration. Sanctions and exchange controls that 
prevented companies from investing abroad were lifted. Many protections for the domestic economy were also withdrawn or substantially reduced. This has coincided with a broader wave of globalisation that has brought national economies closer together as a result of falling transport costs, more mobile capital and labour, technological changes, lower tariff protections and less regulated markets.

Figure 10: Trajectories of main urban agglomerations in economic space related to

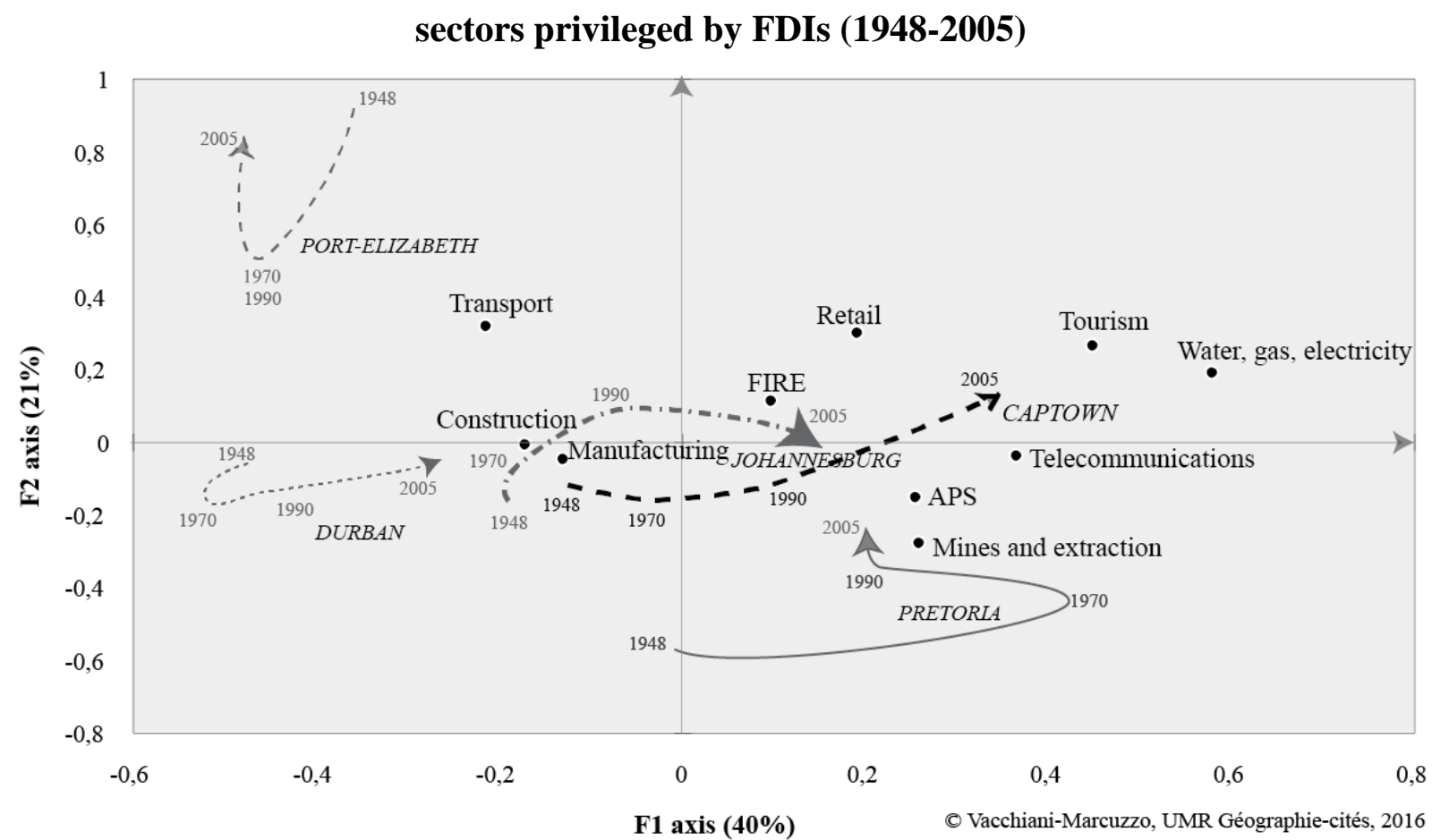

Academics continue to debate whether the improvements in communications and market access associated with 'economic integration' mean more spatially-concentrated activity, or dispersal to a 'flatter' economic landscape. Either way, the fact that the 'world is getting smaller' has created opportunities for South African cities to attract new forms of investment, to serve new markets and develop new economic functions (Vacchiani-Marcuzzo, 2008). Against this, a more open and inter-connected economy also means greater competition for resources and trade, increased import penetration (particularly from China), more pressure to suppress business costs, and greater vulnerability to external shocks. Since 1994 many of South Africa's leading companies have shifted their focus from domestic activities to 'go global' by investing abroad, such as SAB-Miller, BHP Billiton, Naspers, MTN, Anglo American, Old Mutual, Shoprite and Standard Bank. As a result, South African supermarkets, banks, hotel chains and telecommunications firms are now very visible in many African cities. South African companies have been less successful at developing local productive assets and exporting locally made goods. The country's rich natural resource endowments still tend to be exported as raw materials with limited beneficiation and extraction of downstream value from processing and manufacturing.

\subsubsection{Place in the ranking...}

There is a lack of research on how well South African cities are integrated into global flows of finance, trade, talent and information. Global cities develop strong international connections by becoming organising nodes of global business networks. They are primary locations for the headquarters of multinational corporations, financial institutions and specialised business 
services. The performance of cities depends on their economic power and position in the overall hierarchy of world cities. Successful cities are sites of intense interactions involving the exchange of high-level knowledge and technical know-how, which enables them to capture a bigger share of global resource flows. Such cities may encourage the internationalisation of their universities, specialised research and health facilities, and related institutions. The Globalisation and World Cities (GAWC) research network has produced an index of connectedness that is intended to reflect the relative economic power of different cities. It essentially measures the strength of the links between the offices of 100 advanced producer service companies (lawyers, accountants, managing consultants, engineers, marketing, design companies etc.) in 315 cities world-wide (Taylor, 2004). Cities that are strongly networked with other cities are considered to be leading global cities. The index was first produced in 2000 and subsequently updated in 2004, 2008 and 2010. There are three categories of cities. Alpha is defined as "very important world cities that link major economic regions and states into the world economy". Beta is defined as "important world cities that are instrumental in linking their region or state into the world economy". Gamma is defined as "world cities linking smaller regions or states into the world economy, or important world cities whose major global capacity is not in advanced producer services".

Johannesburg is the only African city in the alpha category, according to the 2010 index. It is in $47^{\text {th }}$ and final place in this division. The leading global cities according to the index are London, New York, Hong Kong, Paris, Singapore, Tokyo and Shanghai. There are 15 European cities in the alpha category, 12 from North America, 14 from Asia, three from South America and two from Australia. For Johannesburg to be the only African city in this category is significant. It implies that the city performs a unique role - a kind of gateway function connecting South Africa to the international economy. It may function as a channel for all kinds of resources, people and information, with different economic spin-offs and sources of dynamism for the country and the sub-continent. No other African cities have this profile or reputation, and none can hope to replicate this function in the short-term because it has been built up over decades.

Cape Town is situated in the second division of 64 beta cities (Fig.11), along with three other African cities, Cairo, Casablanca and Lagos. The leading beta cities (ranked just behind Johannesburg) are Dusseldorf, Stockholm, Prague, Montreal, Rome, Hamburg and Manila. Cape Town is in the middle of the range of beta cities: behind Lima, Karachi, Manchester and Bucharest, but ahead of Riyadh, Montevideo and Minneapolis. This also implies that Cape Town performs special role, both in South Africa and in the sub-continent, with all sorts of spillover benefits for the country (Vacchiani-Marcuzzo, 2008). Its function is bound to differ from that of Johannesburg, since its economic structure is distinctive. For example, Cape Town airport is much smaller than OR Tambo, with far fewer international connections.

Durban is ranked towards the bottom of the third category of 67 gamma cities, along with three other African cities, Nairobi, Tunis and Accra. Durban is behind Muscat, Islamabad and Colombo, but ahead of Austin, Belfast and Turin. Durban's position is relatively low considering it is not that much smaller that Johannesburg or Cape Town. This must be because it has a smaller financial and business services sector. In addition, Durban's international functions are more heavily oriented towards manufacturing and port-related logistics activities, which do not feature prominently in the GAWC analysis. Recent investment in the International Convention Centre, King Shaka airport and the Dube Trade Port are aimed strengthening Durban's international position.

Tshwane is in a separate category of cities that are not world cities as defined by GAWC. They are considered to have sufficient services of their own so as not to be dependent on world cities. 
Tshwane's principal functions are domestic - the executive arm of government, the site of higher education, research organisations etc.

\section{Figure 11: Ranking of South African cities according to the GAWC index}

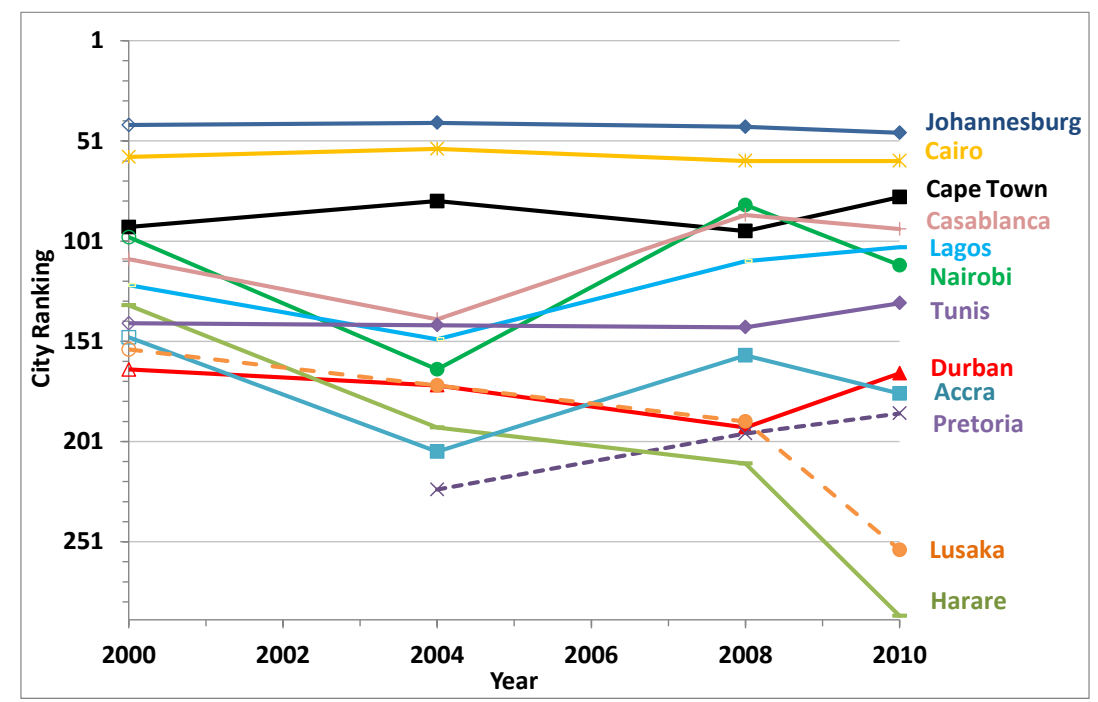

CTurok, 2014

Source: Based on successive reports from GAWC, accessed at: www.lboro.ac.uk/gawc Note: The dotted lines signify incomplete observations

This evidence suggests that most South African cities are not strongly integrated into the global economy, at least for specialised business services. Johannesburg is the exception as the only city in the premier league of highly-connected world cities. Cape Town is in the second category. Durban and Tshwane also feature on the list of world cities, but their global connections seem to be far less significant. Comparing the four indices from 2000 to 2010 enables a simple analysis of the trajectory of these cities over time (Tab.2). Have they become more or less integrated into the world economy during the last decade? One might have expected their integration to increase following the end of South Africa's isolation and the withdrawal of trade protections and tariff barriers during the 1990s.

Table 2 and figure 11 show the ranking of the cities in each period. The picture is quite mixed overall and it is difficult to discern a clear trend. Johannesburg's position has slipped slightly over the decade. This could be linked with the headquarters of several major corporations being transferred to the UK, such as Anglo-American, although the city remains the headquarters of at least seven companies in the Mining Top 100 and the principal location for the major banks and insurance companies (Harrison \& Zack, 2012). Cape Town's position seems to have been quite volatile, with no clear increase or decline. Durban appeared to be slipping until the 2010 index suggested a recovery. Tshwane has move in and out of the index, with no consistent trend over time. Summing up, the main cities have broadly held their own over the last decade, with no general improvement or deterioration in their global standing.

Table 2: Ranking of South African cities according to the GAWC index

\begin{tabular}{|c|c|c|c|c|}
\hline & $\mathbf{2 0 0 0}$ & $\mathbf{2 0 0 4}$ & $\mathbf{2 0 0 8}$ & $\mathbf{2 0 1 0}$ \\
\hline Johannesburg & 43 & 42 & 44 & 47 \\
\hline Cape Town & 94 & 81 & 96 & 79 \\
\hline Durban & 165 & 173 & 194 & 167 \\
\hline Pretoria & n.a. & 225 & n.a. & 187 \\
\hline
\end{tabular}




\begin{tabular}{|c|c|c|c|c|}
\hline Cairo & 59 & 55 & 61 & 61 \\
\hline Nairobi & 99 & 165 & 83 & 113 \\
\hline Casablanca & 110 & 140 & 88 & 95 \\
\hline Lagos & 123 & 150 & 111 & 104 \\
\hline Harare & 133 & 194 & 212 & 288 \\
\hline Tunis & 142 & 143 & 144 & 132 \\
\hline Accra & 149 & 206 & 158 & 177 \\
\hline Lusaka & 155 & n.a. & 191 & 255 \\
\hline
\end{tabular}

CTurok, 2014

Source: Based on successive reports from GAWC, accessed at: www.lboro.ac.uk/gawc

\section{Urban planning and urban future}

\subsection{Rebalancing uneven urbanization}

South Africa's urban system bears the scars of its political history. This is most apparent in its uneven development. The heyday of apartheid between 1950 and the late-1980s was marked by intense efforts to impose racial separation and a hostile anti-urban regime (Turok, 2014). The system was a reaction to the failure of previous state laws to restrict black urbanisation and fears that white settlements would be inundated by Africans. The governing party was desperate to avoid blacks outnumbering whites so they could stay in power with a semblance of legitimacy. Millions of people were forcibly removed from the cities to isolated and barren 'homelands' during this era. A stark gap between urban and rural living standards emerged, creating pent-up migration pressures. Most policies focused on where people lived and resulted in a severe dislocation between the geography of the economy and population. In addition to controlling where people could reside, they also deprived blacks of a decent education and prevented those in the cities from earning a living through self-employment and business startups. This has left a legacy of low business formation rates and high failure rates. Measures were also introduced to steer the location of industry.

In 1960 a regional policy was brought in to promote industrial decentralisation from the main cities. This was South Africa's most enduring form of spatial policy, lasting until 1996 (Todes and Turok, 2017). The 1960s were a period of buoyant economic growth, seemingly offering opportunities to disperse expanding industries. The idea was to encourage factories employing blacks in the cities to move closer to the homelands. The initial focus was on areas bordering the homelands, particularly those thought to have the best prospects and located closest to cities. It was rationalized as 'alleviating over-congestion' in cities and creating jobs near the homelands. In the 1970s the policy was extended to incorporate new planning concepts drawn from abroad. An influential idea was to create large 'growth poles' by locating heavy industry outside the Pretoria-Witwatersrand-Vereeniging region (PWV) (now Gauteng). The 1975 National Physical Development Plan (NPDP) went further with far-reaching proposals for development axes, growth points, deconcentration points and planned metropolitan areas to counterbalance 'over-concentration' in the big cities and to accommodate white out-migration from rural areas. As resistance to apartheid increased during the 1980s, economic problems mounted and policy became more market-friendly. Therefore the policy was revised in 1991, and eventually wound up in 1996.

There has been no systematic attempt to assess the impact of this policy. Other spatial initiatives were introduced after 1994, but in a rather fragmented, inconsistent and even contradictory way. In the absence of an overarching national spatial vision and plan, different government departments and entities have pursued their own agendas and initiatives. Two programmes are 
worth mentioning, both aiming to steer investment and growth towards specific areas in order to re-balance the economic geography of the country and create attractive spaces through economic incentives (Rogerson, 2001).

- Spatial Development Initiatives (SDIs) were introduced in 1996 at the time the industrial decentralisation policy was dismantled. SDIs were seen as a means of stimulating growth in regions with unrealised potential, realising this would need more than mere incentives (Todes and Turok, 2017). SDIs sought to 'unlock' this potential through targeted actions to enhance infrastructure and encourage new investment. This would require coordination across the public sector and was consistent with the new government's macro-economic strategy of supporting growth led by the private sector and focused on exports. The intention was to tackle apartheid spatial problems in ways that would enable marginal locations to become internationally competitive. This meant attracting inward investment in manufacturing. A second objective was to support economic empowerment through small business development, thereby broadening economic ownership.

Eleven SDIs were designated across the country: Maputo Corridor, Phalaborwa, Platinum, West Coast Investment Initiative, Fish River, Wild Coast, Richards Bay, Durban and Pietermaritzburg, Lubombo and the Gauteng Special Zones. Most were in rural areas or small towns. Each SDI was supposed to be a short, sharp institutional intervention lasting 12-18 months, then transferred to the province or local investment promotion agency. In practice, most SDIs lasted for around three years. They were reasonably successful at developing infrastructure. The public-private partnership approach generated extra investment that would have been difficult otherwise. Yet the SDIs failed to deliver anything like the numbers of jobs expected (Todes and Turok, 2017). Some locations were selected for political reasons and failed to attract private investment. Several project proposals put to investors were simply unrealistic. Weak institutional capacity and political conflicts in several places also hampered SDI processes. They were sometimes treated as substitutes for government action, and they suffered from poor coordination between departments. Their timescales were also too short to achieve meaningful impacts on the ground in many places.

- Industrial Development Zones (IDZs) were the other national spatial programme implemented from 2000. They were special zones linked to a seaport or airport and designed for exportrelated industries. IDZs were supposed to create jobs by attracting foreign direct investment and exporting value-added commodities through a standard package of incentives (Todes and Turok, 2017). Three IDZs were designated during the 2000s: Coega, East London and Richards Bay. All were publicly owned and run, in some cases with the involvement of provincial or municipal government. IDZs were supposed to offer world-class infrastructure and utilities linked to an international port of entry and simplified administrative procedures. However, extra-territorial customs secured areas were not implemented, and many incentives were identical to those available outside the zone. Therefore, the programme was very slow to take effect and heavily criticised for its weak policy framework; poor governance arrangements; $a d$ $h o c$ funding that prevented long-term planning in the IDZ; lack of special incentives or targeted investment promotion; inadequate strategic direction, and poor coordination. Consequently, the IDZs are currently being transformed into Special Economic Zones with enhanced support.

Both SDIs and IDZs have been criticised for their top down approach and failure to involve local communities (Bek, et al., 2004). They illustrate the difficulties involved in rebalancing the country's uneven development with the need for global competitiveness. There was also a lack of consistency and follow-through across government, resulting in a failure to generate any kind of development momentum in most locations. 


\subsection{Consolidation of the metropolitan archipelago}

Simultaneously, the need to address the deep socio-spatial divisions within the major cities explains the creation of six metropolitan-wide authorities in 2000. Another intention was to capitalize on the economic strengths of the large cities, at the risk of reinforcing the inherited disparities with the countryside.

South African cities remain among the most polarised places in the world. The ideological drive for racial separation resulted in the creation of highly segregated settlements, with many damaging effects. Since the advent of democracy in 1994, there has been strong support for universal human rights and progressive social policies - i.e. a kind of people-centred, pro-poor approach. However, geographical inequalities have received less direct attention because spatial gaps are difficult to address and a sense that territories should be treated even-handedly. Nevertheless, amalgamating the fragmented system of racially-based local authorities has been an important first step.

This process of organisational restructuring resulted in the establishment of single tier metropolitan governments for each major city (eThekwini, Tshwane, Ekurhuleni, Nelson Mandela Bay, Cape Town and Johannesburg). Their first task was to tackle the inherited 'backlogs' by extending the provision of basic services to the black townships. They made good use of the accumulated reserves of the former white municipalities and additional revenues raised from the established suburban tax base (Turok, 2014). 'Service delivery' became the mantra, implying the extension of electricity, water, sanitation, roads, refuse collection and even free housing to historically-disadvantaged communities.

The creation of the six metros with their own administrations, large territories and relatively strong tax bases and planning tools reinforced a perception that these cities could "look after themselves" financially and technically (Turok, 2014). Along with some lingering resentment of historically "white" cities within the ruling party, the result was less support or active interest from national government than one might have anticipated. Some officials recognised that the metros ought to drive national economic growth in a more competitive global context by reinvesting a sizeable share of national tax revenues in improved urban infrastructure, but the prevailing view was that diverting resources to address poverty and lack of institutional capacity in rural areas was the priority. The relationships between the metros and provincial governments were complicated by power struggles and several metros complained that the provincial budgets for schools and hospitals were skewed away from the cities and towards the rural areas. Hence, the political rescaling of government after 1994 contributed to new spatial tensions within the country.

Unequal growth across South Africa has been described as "shop window" development by C. Bénit and P. Gervais-Lambony (2003) because of the skewed policies aimed at attracting elites, local and foreign capital and tourism back to the main metropolitan centres. This has been promoted through public-private partnerships and by hosting major events so as to raise international visibility. For example, Johannesburg welcomed the Earth Summit in 2002 and the international AIDS Conference in 2003. Durban hosted the Climate Change Conference in 2011 and Cape Town became World Design Capital in 2014. The 2010 FIFA World Cup undoubtedly made the biggest impact because of the sheer number of visitors attracted by the event. Hosting these events was fostered by energetic marketing campaigns: Johannesburg brands itself a "World Class African City", insisting on its position as the biggest financial centre on the continent. Durban's vision is to be Africa's most caring and liveable city by 2030. Cape Town's logo shows Table Mountain and its slogan making progress possible together refers to the city's natural asset and its economic spinoffs. All three cities are acutely aware of the need to position themselves in a wider global context if their economies are to prosper. 
The consolidation of the biggest cities is fostered by the creation of transport corridors linking Johannesburg-Pretoria, Durban and Cape Town. The liberalisation of the aviation sector in the 1990s opened the market to new competitors. Even though during the first decade the hegemony of South African Airways was maintained, the opening of the market to low-cost airlines changed the sector and boosted the number of airline passengers (Luke \& Walters, 2013). Internal routes focus on Johannesburg as a hub with strong links to Cape Town and Durban. Airline operators use the term "golden triangle" to describe the connections between these cities. Regarding the railway network, there has been a reduction in the passenger service between the main cities, and various railway lines have been closed. The railway offer for passengers is concentrated on the Cape Town-Johannesburg line, which benefits from Economy and Tourist trains as well as luxury services with the Premier Class Train and Blue Train. Johannesburg-Durban also has a reasonably frequent passenger service. The consolidation of specific transport links and the creation of corridors at a national scale contribute to the formation of a metropolitan archipelago. This process can be understood as the consequence of uneven spatial development inherited from apartheid combined with polarization related to globalisation and competitive pressures.

\subsection{South African cities: from fragmented spaces towards innovation in urban planning?}

South African cities have faced new challenges since 1994. The spatial mismatch between jobs and housing inherited from apartheid has been exacerbated since the end of apartheid by market processes and state housing programmes. The deconcentration and dispersal of middle class groups and economic activity from the city centres has been analysed by various researchers (Guillaume, 1997; Turok, 2001; Hindson, 2002) who identified centrifugal dynamics leading to patterns of re-segregation. The relocation of better-off consumers in new suburban areas promoted the displacement of retail activity, entertainment and other householdrelated services. Suburban centres tend to be well connected to the road infrastructure, but poorly linked to the main public transport networks, thereby worsening access to jobs and services for the black majority of the population.

Municipal spatial plans have generally made the case for urban integration and densification, but they have had insufficient influence over government infrastructure decisions or over the private sector to achieve this (Turok, 2014). Since 1994 the government has attached particular importance to building subsidised housing. There has been less support for upgrading squatter settlements because they are unauthorised and working with these communities is complicated. It seems easier and more popular to provide everyone with a formal housing unit on its own site. Financial constraints have required limiting the cost of land, hence focussing on marginal sites with few rival land users. Provincial governments have controlled the housing budgets, but local authorities have to pay for the main infrastructure. Struggling to sustain a high level of housing delivery, National Treasury offered a new Urban Settlements Development Grant (USDG) in the late-2000s to cover the costs of land, infrastructure and household services that municipalities were unable to afford. It is estimated that about 3 million state-subsidised houses have been built to date, for a fifth of all citizens. In sheer quantitative terms this is a notable achievement that has benefited people's quality of life and dignity (Turok, 2015).

Yet, important limitations have also come to light, including a declining rate of delivery, higher costs, inferior construction methods, and evidence of patronage, fraud and corruption in issuing tenders and managing waiting lists for the housing (Turok, 2014). Migration has meant that the housing backlog continues to increase, and community protests over public services have escalated. Many people have doubted whether it is feasible to build millions more of these free houses, especially when most families cannot afford the cost of ongoing services, property 
maintenance and daily consumption needs. Some statistics suggest that less than one in three RDP homeowners have a job. Housing has taken the form of physical shelter, not part of a rounded human settlement with access to amenities, community services and jobs. The effect has been to reproduce the extensive spatial form of the apartheid city, in contrast to the commitment to create sustainable human settlements that was made in 2004. The housing programme has also damaged sensitive ecosystems and been wasteful to water, energy and other natural resources. Cities in South Africa are unusual in the world in that the average population density increases with distance from the centre. This is a source of inefficiency and inequity, and conditions appear to have worsened in the last two decades.

Transport policy has also experienced continuity with the past. In effect it has to compensate for the lack of restructuring of the urban form. The public transport system is fragmented with different modes of travel answerable to different parts of government, and no simple arrangements for passengers. Travel subsidies favour existing bus and train operators and neglect minibus taxis, despite them being used by most low income commuters. Commuting times for black households have risen from an average of 88 to 102 minutes a day over the past decade because of the peripheral location of new housing and delayed public transport reforms (Turok, 2015). Citizens commuting to work by public transport spend 2.5 times longer in transit than Europeans, and twice as long as Americans. The governance of public transport is beginning to change in several cities to enable more integrated systems managed by single transport authorities. There is a gradual process of devolution of responsibility for commuter trains and bus services underway which should permit more sensible planning of different services and ultimately a seamless public transport network. New bus rapid transit systems are also being introduced in the big cities. New public investment should mean that the quality improves and public transport becomes more than a last resort means of mobility for very poor people. Making public transport in South African cities more viable (and reducing the high level of government subsidies) will also require raising population densities along transport corridors because the current sprawling settlement pattern is a source of great inefficiency.

\section{Conclusion}

The South African urban system is a relevant laboratory for analysing urban trajectories in emerging economies. Several urbanization processes have comparable features to those of other countries, such as the extensive, sprawling and fragmented growth of individual towns and cities. Other aspects are more distinctive and reflect the country's political history, such as the stark patterns of urban segregation and the displaced urbanization in and around the homelands. The opening-up of the economy, and its insertion in global markets and networks, has created a harsher and more competitive environment for trade and investment, with problems generated in terms of rising unemployment, poverty and inequality. The challenging context creates many tensions and trade-offs for contemporary decision-makers, with difficult balances to be struck between private interests and public goods, economic efficiency and social equity, higher productivity and balanced development, and accelerated growth versus social inclusion and cohesion.

\section{References}

Baffi S. (2014). Chemins de civilisation? Le rail dans les politiques territoriales en Afrique du Sud. L'Espace géographique, vol. 43, n 4, pp. 338-355.

Bek D., Binns T. \& Nel E. (2004). Catching the development train: perspectives on "top down" and "bottum up" development in post-apartheid South Africa. Progress in development studies, vol. 4, $\mathrm{n}^{\circ}$ 1, pp. 22-46. 
Bénit C., Gervais-Lambony P. (2003). La mondialisation comme instrument politique local dans les métropoles sud-africaines (Johannesburg et Ekhuruleni): les "pauvres" face aux "vitrines". Annales de Géographie, $\mathrm{n}^{\circ}$ 634, pp. 628-645.

Bickford-Smith, B., van Heyningen, E. and Worden, N. (1999) Cape Town in the Twentieth Century: An Illustrated Social History. Cape Town: David Philip, 283 p.

Bhorat, H., Cassim, A. \& Hirsch, A. (2014) Policy co-ordination and growth traps in a middle-income country setting: The case of South Africa. WIDER Working Paper 2014/155, Helsinki: UNU-Wider.

Browett, J.G., Fair T.J.D. (1974). South Africa, 1870-1970: A View of The Spatial System. South African Geographical Journal, vol. 56, n 2, pp. 111-120.

Coquéry-Vidrovitch C. (1993). La ville coloniale "lieu de colonisation" et métissage culturel. Afrique contemporaine, numéro spécial, pp. 11-22.

Davies R.J. (1972). The urban geography of South Africa. Institute for social research, Durban: University of Natal, $259 \mathrm{p}$.

Freund, B., Padayachee, V. (2002). (D)urban Vortex: South African City in Transition. Pietermaritzburg: University of Natal Press, 345 p.

Giraut F., Vacchiani-Marcuzzo C. (2009). Territories and urbanization, Atlas and geo-historical information system (DYSTURB). Paris: IRD éditions, CD Rom, $80 \mathrm{p}$.

Guillaume P. (1997). Du blanc au noir... Essai sur une nouvelle ségrégation dans le centre de Johannesburg. L'Espace géographique, vol. 26, n 1, pp. 21-33.

Harrison, P. \& Zack, T. (2012) The power of mining: the fall of gold and rise of Johannesburg. Journal of Contemporary African Studies, 30(4), pp.551-570.

Houssay-Holzschuch M. (1999). Le Cap ville sud-africaine, Ville blanche, vies noires. Paris: l'Harmattan, coll. « Géographie et cultures », 276 p.

Hindson D. (2002). Fragmentation et intégration dans une ville de l'après apartheid: le cas de Durban. In Navez-Bouchanine F. La fragmentation en question. Paris: L'Harmattan, 411 p.

Jefferson M. (1939). The Law of Primate City. Geographical Review, n² 29, pp. 226-232.

Luke R. \& Walters, J. (2013). Overview of the developments in the domestic airline industry in South Africa since market deregulation. Journal of Transport and Supply Chain Management, vol. $7, \mathrm{n}^{\circ} 1$, pp. 1-11.

Mc Kenzie R.D. (1927). The concept of dominance and world-organization. American Journal of sociology, vol. 33, $\mathrm{n}^{\circ} 1$, pp. 28-42.

Moriconi-Ebrard F. (1993). L'urbanisation du monde. Paris, Anthropos, Economica, Collection Villes, $372 \mathrm{p}$.

Paulus F., \& Vacchiani-Marcuzzo C. (2016). Knowledge industry and competitiveness: Economic trajectories of French urban areas (1962-2008). In A. Cusinato, A. Philippopoulos-Mihalopoulos, Knowledge-creating Milieus in Europe: Firm Cities, Territories. Springer, pp. 157-170.

Pumain D., Paulus F., Vacchiani-Marcuzzo. (2009). Innovation Cycles and Urban Dynamics in D. Lane, D. Pumain, S. Van der Leeuw, G. West (eds.), Complexity perspectives on innovation and social change, ISCOM, Springer, Methodos Series, 237-260.

Pumain D., Paulus F., Lobo J. \& Vacchiani-Marcuzzo C. (2006). An evolutionary theory for interpreting urban scaling laws. Cybergeo, $\mathrm{n}^{\circ} 343$, http://cybergeo.revues.org/2519

Rogerson C.M. (2001). Spatial development initiatives in Southern Africa: The Maputo Development Corridor. Tijdschrift voor Economische en Sociale Geografie, vol. 93, n 2, pp. 324-346.

Taaffe E. J., Morrill R. L. \& Gould P. R. (1963). Transport expansion in under-developed countries. The Geographical Review, $\mathrm{n}^{\circ}$ 53, pp. 503-529 
Taylor, P. J. (2004). World City Network. London: Routledge. 256 p.

Todes, A. \& Turok, I. (2017). Spatial Inequalities and Policies in South Africa: Place-based or Peoplecentred? Progress in Planning. http://dx.doi.org/10.1016/j.progress.2017.03.001

Turok I. (2001). Persistent polarization Post-apartheid? Progress towards urban integration in Cape Town. Urban Studies, vol. 38, n 13, pp. 2349-2377.

Turok, I. (2014) South Africa's tortured urbanization and the complications of reconstruction. In Martine, G. and McGranahan, G. Urban Growth in Emerging Economies: Lessons from the BRICS. London: Routledge. 288 p.

Turok, I. (2015). South Africa's new urban agenda: Transformation of compensation? Local Economy. DOI: $10.1177 / 0269094215614259$

Vacchiani-Marcuzzo C. (2016). L'Afrique du Sud est-elle un cas à part? Analyse d'une hybridité urbaine (Is South Africa apart? Assessment of an urban hybridity), Habilitation à diriger des recherches, Université Paris 1 Pantheon-Sorbonne, 2 vol.

Vacchiani-Marcuzzo, C. (2008). Quelle place pour le Cap dans la mondialisation? Stratégies spatiales des IDE et dynamique urbaine. In Dubresson A., Jaglin S., Le Cap après l'apartheid. Gouvernance métropolitaine et changement urbain. Paris: Karthala, 157-182. http://halshs.archivesouvertes.fr/halshs-00333685

Woolf S.E. \& Joubert J.W. (2013). A people-centred view on paratransit in South Africa. Cities, vol. 35 , pp. 284-293. 